\title{
Optimal financial crises: A note on Allen and Gale
}

\author{
François Marini
}

Received: 6 May 2005 / Revised: 6 May 2006

(C) Springer Science + Business Media, LLC 2006

\begin{abstract}
This note provides an example of an optimal banking panic. We construct a model in which a banking panic is triggered by the banker, not the depositors. When the banker receives a pessimistic information on the return on the bank's assets, he liquidates them prematurely in order to protect his capital. In the face of this liquidation, all depositors withdraw their funds prematurely. The premature liquidation of the bank's assets strengthens the bank's balance sheet. As a result, the banking panic does not cause bank failure and the government should not try to prevent the panic. Such a panic occured in 1857 in the United States.
\end{abstract}

Keywords Optimal banking panic $\cdot$ Bank failure $\cdot$ Deposit insurance $\cdot$ Panic of 1857

\section{JEL Classification G21}

\section{Introduction}

In the current literature, banking panics are viewed as a liquidation of the banks' assets which is triggered by a bank run. Bank runs can be due to a destabilizing behavior by depositors modeled as a sunspot equilibrium. These speculative bank runs are modeled in Diamond and Dybvig [1983]. Bank runs can also be insolvency-based. When depositors receive a pessimistic information on the return on the bank's assets, they expect that the bank will be insolvent. As a result, they rush to withdraw their funds, forcing the bank to liquidate prematurely its assets. These efficient bank runs are discussed in Freixas and Rochet [1998].

In comparison with a lender of last resort, the specific goal of deposit insurance is to prevent insolvency-based bank runs. According to the Bagehot principles, the lender 
of last resort should lend only to illiquid but solvent banks. The lender of last resort allows the bank to pay off its depositors without having to liquidate the bank's assets at fire-sale prices. Deposit insurance is a different policy because it ensures depositors that they will be paid off even if the bank's assets have been liquidated, i.e., even if the bank is insolvent.

Allen and Gale [1998] show that the welfare costs of financial crises are due to the fact that they lead to the inefficient liquidation of the banks' assets and suboptimal risk sharing. In other words, the problem is not bank runs per se, but the fact that they cause unnecessary liquidations. This is an important insight because the normative analysis of financial crises (i.e., the analysis of the optimal policy towards crises) is related to the positive analysis of crises (i.e., the analysis of the causes of financial crises, and what happens during a financial crisis). The optimal policy towards crises is not necessarily to prevent them. It is rather to minimize their costs.

In the benchmark version of their model, Allen and Gale [1998] provide an example in which a banking system subject to runs can achieve the first-best allocation. This is because deposit contracts are not contingent while the optimal allocation is contingent on a leading indicator of the business cycle. Bank runs implement the first-best allocation because they produce the right degree of contingency. Samartin [2003] shows that this result depends on the utility function of the typical depositor.

In comparison with Allen and Gale [1998], the insight of this note is that it is important to realize that banking panics do not necessarily lead to bank failures. A bank may fail without a panic occuring, and panics may not lead to failures. This is clear from a reading of the historical literature, for example Sprague [1910], or Wicker [2000]. A bank failure is similar to any other type of business failure: a bank cannot meet its promises to pay, and property rights are reassigned by the legal authority. A panic is a period when there is a large shift in the demand for government liabilities relative to the liabilities of the banking system. This is an interesting insight because policies such as the lender of last resort and deposit insurance are based on the belief that speculative and efficient bank runs must be prevented because they cause bank failures which are more damaging to the macroeconomy than are failures of firms in other industries (for example because they break long-standing bank-customer relationships and they disrupt the payment system).

In this note, we construct a simple model in which a banking panic does not necessarily cause an inefficient liquidation of the banks' assets and does not lead to bank failures. We extend Marini [2003] by assuming that the banker receives an information on the return on the bank's assets. In our model, a banking panic is triggered by the banker, not the depositors. When the banker receives a noisy pessimistic information on the return on the bank's assets, he liquidates them prematurely in order to protect his capital. This premature liquidation allows the banker to strengthen the bank's balance sheet. In the face of this liquidation, all depositors withdraw their funds prematurely because the bank will have no asset left at the final period. However, the bank is not bankrupt because all depositors are paid off in the interim period at the promised return. Hence, we have an information-based banker panic which allows to prevent the bank failure. According to Gibbons [1859] and Van Vleck [1943], such a panic occured in 1857 in the United States. This bank-initiated banking panic may be a preventive action that turned out to be inadequate on an ex-post basis because the banker's information is noisy. However, the banker acts rationally conditionally 
on his information. If the government is not better informed than the banker, it should not try to stop the premature liquidation.

The note is organized as follows. In Section 2 we describe the model. In Section 3 we show that our model can explain some stylized facts emphasized by Gibbons (1859) and Van Vleck [1943].

\section{The model}

Following Marini [2003, 2005], we distinguish between two types of financial intermediaries. The first type is a mutual bank which maximizes the expected utility of its depositors and earns no profits. The second type of financial intermediary is a capitalized bank that issues demand deposit contracts and equity. A capitalized bank maximizes the expected utility of the banker that owns the equity.

\subsection{The mutual bank}

There are three time periods, $T=0 ; 1 ; 2$. Each agent is endowed at $T=0$ with one unit of the consumption good. An agent's intertemporal preferences for consumption are:

$$
u= \begin{cases}u\left(c_{1}\right) & \text { with probability } t \\ u\left(c_{2}\right) & \text { with probability } 1-t\end{cases}
$$

where $c_{T}$ is the consumption at $T$. An agent who wants to consume at $T=1$ is called a type 1 agent, while an agent who wants to consume at $T=2$ is a type 2 agent. Agents do not know their types in the planning period $T=0$ but discover them at $T=1$. Knowledge of one's type is private information. There is only one production technology. For an investment of 1 at $T=0$, the technology yields 1 at $T=1$ if the investment is liquidated at $T=1$, or $\widetilde{R}$ at $T=2$ if it is liquidated at $T=2$. The stochastic return $\widetilde{R}$ has a two-point support:

$$
\widetilde{R}=\left\{\begin{array}{l}
R(H)>1 \text { with probability } P(H) \\
R(L)<1 \text { with probability } P(L)
\end{array}\right.
$$

with $E[\widetilde{R}]=P(H) R(H)+P(L) R(L)>1$. The bank maximizes the expected utility of its depositors subject to its budget constraints and an incentive-compatibility constraint which guarantees that at $T=1$ a type 2 agent does not have an interest in lying, i.e., claiming to be a type 1 agent:

$$
\operatorname{Max} t u\left(r_{1}\right)+(1-t) P(H) u\left(r_{2 H}\right)+(1-t) P(L) u\left(r_{2 L}\right),
$$

subject to:

$$
\begin{aligned}
t r_{1} & \leq y, \\
(1-t) r_{2 H} & =R(H)(1-y)+y-t r_{1}, \\
(1-t) r_{2 L} & =R(L)(1-y)+y-t r_{1}, \\
P(L) u\left(r_{2 L}\right) & +P(H) u\left(r_{2 H}\right) \geq u\left(r_{1}\right),
\end{aligned}
$$


where $y$ is the quantity of assets which are liquidated at $T=1, r_{1}$ is the consumption of a type 1 agent at $T=1, r_{2 L}$ is the consumption of a type 2 agent at $T=2$ when $\widetilde{R}=R(L)$, and $r_{2 H}$ is the consumption of a type 2 agent at $T=2$ when $\widetilde{R}=R(H)$.

\subsection{The capitalized bank}

We introduce a type 3 agent not in need of liquidity at $T=1$ and endowed with $K$ units of the consumption good per capita. This agent is called the banker. At $T=0$, the banker is sure that he will want to consume at $T=2$. For simplicity, we assume that the banker is risk-neutral. A capitalized bank is a bank which issues demand deposits and equity. The banker can increase his expected consumption at $T=2$ by setting up a capitalized bank. This is because type 2 agents are risk averse. So there is a $\bar{r}_{2}$ satisfying $\bar{r}_{2}<P(H) r_{2 H}+P(L) r_{2 L}$ and $u\left(\bar{r}_{2}\right)>P(H) u\left(r_{2 H}\right)+P(L) u\left(r_{2 L}\right)$. This means that the banker can increase the expected utility of type 2 agents by promising them a certain return smaller than the expected return of the deposit contract issued by a mutual bank.

Now, let $r_{2}^{*}$ defined by $u\left(r_{2}^{*}\right)=P(H) u\left(r_{2 H}\right)+P(L) u\left(r_{2 L}\right)$. In other words, $r_{2}^{*}$ is the certainty equivalent of the deposit contract issued by a mutual bank. The banker can increase his expected consumption by setting $\bar{r}_{2}=r_{2}^{*}+\varepsilon$ with $\varepsilon>0$ sufficiently small. He insures depositors against the technological risk because he promises them a certain return at $T=2$.

In Allen and Gale [1998], at $T=1$ depositors observe a signal which predicts the value of $R$ at $T=2$ with perfect accuracy. In this note, we assume that at the beginning of the period $T=1$, i.e., before depositors decide to withdraw or not to withdraw, the banker receives a noisy signal. With this imperfect information, he updates $P(H)$ and $P(L)$ using the Bayes rule. Following Jacklin and Bhattacharya [1988] we assume that the deposit contract is not contingent on the information received at $T=1$. For simplicity, we assume that the banker can receive an optimistic information $s_{o}$ or a pessimistic information $s_{p}$. We interpret a pessimistic information as a leading indicator of recession. We denote $P\left(H / s_{p}\right)$ and $P\left(L / s_{p}\right)$ the a-posteriori probabilities conditional on $s_{p}$. Obviously, $P\left(H / s_{p}\right)<P(H)$, and $P\left(H / s_{o}\right)>P(H)$.

If the banker receives the pessimistic information $s_{p}$, he must decide whether he liquidates the bank's assets or not. If he does not liquidate, his expected profit is $E\left(\tilde{\pi} / s_{p}\right)=\left(1+K-t r_{1}\right) E\left(\widetilde{R} / s_{p}\right)-(1-t) \bar{r}_{2}$. Note that since the interest rate is nil between $T=1$ and $T=2, E\left(\widetilde{\pi} / s_{p}\right)$ is the discounted expected profit of the banker. Hence, in a world of risk neutrality, $E\left(\tilde{\pi} / s_{p}\right)$ is the market value of the bank's assets, i.e., bank capital on a market-adjusted basis. If the banker liquidates, there is a credit crunch. We assume that depositors are informed that there is a credit crunch. This is perhaps because they can observe the rise of business failures. When there is a credit crunch, depositors withdraw their funds at $T=1$ because the bank will have no asset at $T=2$ to pay off $\bar{r}_{2}$. So the profit of the banker is $K+1-r_{1}$. The banker liquidates if $E\left(\tilde{\pi} / s_{p}\right)<K+1-r_{1}$, i.e., if bank capital on a market-adjusted basis is lower than the net worth at $T=1$. This is because by liquidating he protects his capital against an expected loss. Therefore, depositors withdraw their funds. This is because when there is a credit crunch at $T=1$, the bank is insolvent at $T=2$. This bank run is triggered by the banker. It is not triggered by a destabilizing behavior from depositors. 
The table gives the New York clearing house figures for the period from August 22 to September 26 in round numbers (in US dollars)

\begin{tabular}{llrll}
\hline Week ending & Loans & \multicolumn{1}{l}{ Specie } & Circulation & Deposits \\
\hline August 22 & 120140000 & 10097000 & 8694000 & 64241000 \\
August 29 & 116589000 & 9241000 & 8671000 & 60861000 \\
September 5 & 112221000 & 10228000 & 8673000 & 57261000 \\
September 12 & 109986000 & 12182000 & 8322000 & 57334000 \\
September 19 & 108777000 & 13556000 & 8074000 & 57852000 \\
September 26 & 107791000 & 13327000 & 7838000 & 56919000 \\
\hline
\end{tabular}

Source: Van Vleck (1943), p. 70

When the banker strengthens the bank's balance sheet by reducing its loans, he is able to pay off $r_{1}$ at $T=1$ to each depositor because $1+K>r_{1}$. Hence, the bank is not bankrupt because the banker is able to meet his promises to pay at $T=1$. We have a banking panic which does not lead to bank failure. Balance sheet strengthening allows to prevent bank failure.

It is possible that the banker liquidates the assets at $T=1$ and the state of nature turns out to be $H$ at $T=2$. That is, liquidation at $T=1$ turns out to be inadequate at $T=2$. However, liquidation at $T=1$ is rational (bayesian rationality) conditionally on the noisy signal $s_{p}$. If the government is not better informed than the banker, this bank-initiated banking panic is optimal ex-ante and should not be prevented.

\section{The panic of $\mathbf{1 8 5 7}$}

It is beyond the scope of this note to make an exhaustive study of the panic of 1857. More advanced studies are Gibbons [1859], Van Vleck [1943], Temin [1975], Huston [1983, 1987], and Calomiris and Schweikart [1991]. We simply want to emphasize that according to Gibbons [1859] and Van Vleck [1943], the kind of panic that we have modeled in the previous section seems to have occured in 1857.

In the table, we can see the New York Clearing House figures for the period from august 22 to september 26 in round numbers (in US dollars).

These numbers show that while the banks were forcing a contraction of their loans to the extent of more than $\$ 12000000$ in five weeks, the confidence of the public was still persisting at a remarkably high level. The most violent liquidation was between September 5th and September 19th, when the loans were reduced \$3444000 in the face of an increase of deposits of $\$ 591000$. As pointed out by Gibbons [1859, p. 354]:

"There can be no escape from these figures. They show beyond cavil, that the banks, not the depositors, took the lead in forcing liquidation".

It was not until October that depositors rushed to withdraw their deposits. September 29 witnessed business houses failures at an appaling rate in Chicago. In the early days of october, business failures were announced on every side of the country. On october 10, three great railroad companies, the Erie, the Michigan Central, and the Illinois Central, failed to meet their engagements. By the evening of october 14, suspension of deposits convertibility was general throughout the nation.

According to Gibbons [1859, p. 361]: 
"The history of the panic is clearly divisible into these two periods: the former, when the banks took the initiative in forcing down their loans; and the latter, in which the depositors seized it and brought on the closing act of suspension."

Our model is also consistent with the fact that few banks failed during the banking panic of 1857. For example, Dwyer and Hafer [2001] choose to examine the panic of 1860 rather than that of 1857 because so few banks failed in 1857. The lack of failure could have been the result of the strengthening of bank balance sheets on the basis of interim information.

Acknowledgments The author thanks two anonymous referees for very helpful comments.

\section{References}

ALLEN, F. and GALE, D. [1998]: "Optimal Financial Crises," Journal of Finance, 53, 1245-1284.

CALOMIRIS, C. and SCHWEIKART, L. [1991]: "The Panic of 1857: Origins, Transmission, and Containment," Journal of Economic History, 51, 807-834.

DIAMOND, D. and DYBVIG, P. [1983]: "Bank Runs, Deposit Insurance, and Liquidity," Journal of Political Economy, 91, 401-419.

DWYER, G. and HAFER, R. [2001]: "Bank Failures in Banking Panics: Risky Banks or Road Kill?," Federal Reserve Bank of Atlanta Working Paper, $\mathrm{n}^{\circ} 2001-13$.

FREIXAS, X. and ROCHET, J-C. [1998]: Microeconomics of Banking, The MIT Press.

GIBBONS, J.S. [1859]: The Banks of New York, Their Dealers, The Clearing House, and The Panic of 1857. New York: D. Appleton \& Co.

HUSTON, J. [1983]: "Western Grains and the Panic of 1857," Agricultural History 57.

HUSTON J. [1987]: The Panic of 1857 and the Coming of the Civil War. Baton Rouge.

JACKLIN, C. and BHATTACHARYA, S. [1988]: "Distinguishing Panics and Information-based Bank Runs: Welfare and Policy Implications," Journal of Political Economy, 96, 568-592.

MARINI, F. [2003]: "Bank Insolvency, Deposit Insurance, and Capital Adequacy," Journal of Financial Services Research, 24, 67-78.

MARINI, F. [2005]: "Banks, Financial Markets, and Social Welfare," Journal of Banking and Finance, 29, 2557-2575.

SAMARTIN M [2003]: "On the Optimality of Bank Runs: Comment on Allen and Gale," The Geneva Papers on Risk and Insurance Theory, 28, 33-57

SPRAGUE, O.M.W. [1910]: History of Crises Under The National Banking Era, National Monetary Commission. Washington D.C: Government Printing Office

TEMIN, P. [1975]: “The Panic of 1857," Intermountain Review, 6, 1-12.

VAN VLECK, G. [1943]: The Panic of 1857. New York: Columbia University Press.

WICKER, E. [2000]: Banking Panics of the Gilded Age. Cambridge University Press. 